\title{
When the Other Speaks: Ismā'îl Gasprinskii and the Concept of Islamic Reformation
}

\author{
Gulnaz Sibgatullina | ORCID: 0000-0001-5628-5920 \\ Amsterdam School for Regional, Transnational, and European Studies, the \\ University of Amsterdam, the Netherlands \\ g.r.sibgatullina@uva.nl
}

\begin{abstract}
Through analysis of the Russian-language writings of the prominent Crimean Tatar Muslim educator Ismāîl Gasprinskii, this article engages in unpacking the term 'Islamic Reformation'. Gasprinskii's membership of various, not necessarily overlapping social groups, including Russian conservative circles and international Muslim liberal networks, gave rise to the multitude of complex, often mutually exclusive meanings that the term enjoyed in his work. Despite clear references that Gasprinskii made to European and global Islamic discourses on civilisation and progress, his texts remained highly sensitive to Russia's own insecure stance vis-à-vis Europe. Responding to the nation-building rhetoric of Russia's elites, Gasprinskii conformed to and simultaneously challenged dominant cultural codes concerning Russia's ethnic and religious minorities in many subtle ways. His case thus invites a reconsideration of the modes of conversation that existed between the coloniser and the colonised at the turn of the twentieth century, whereby we see them not as instances of uncontested domination by and imposition of European models, but as a complex and multidirectional process in which Muslim figures, like Gasprinskii, could exercise a significant degree of agency.
\end{abstract}

\section{Keywords}

Islamic Reformation - Protestant Reformation - Ismā̄̄ll Gasprinskii - Sayyid Aḥmad Khān - cultural hybridity 


\section{Introduction}

The (re)interpretation of roots, manifestations and effects of the Muslim reformist movement in the Russian empire of the nineteenth to early twentieth centuries - the movement that has until recently been subsumed under the umbrella term Jadidism (from ușül-i jadìd, 'new method' of schooling) continues to fuel discussions among scholars of Russia's Islam. ${ }^{1}$ Recent work on the topic, including certain widely-cited publications that have appeared in this journal, has challenged and deconstructed the previously dominant, dichotomous division of Muslim actors into reactionaries and modernisers, thereby urging a more critical engagement with a broad array of currents within the phenomenon of Muslim modernism. ${ }^{2}$ This paper draws on the ongoing scholarly conversation in the field and seeks to further problematise the nature of changes in Russia's Muslim communities of the time by scrutinising our understanding of the agency that prominent Muslim figures maintained and exercised in their interaction with Russian imperial institutions. Such an approach not only encourages a more sophisticated view of the Muslim reformist agenda but also enables the dismantling of an ingrained but misleading imagery of sharp boundaries between Muslim intellectuals and their Russian/Orthodox Christian counterparts.

Central to the perspective explored in this paper is Ismâîl Gasprinskii (Gaspirall, 1851-1914), a well-known Crimean Tatar reformer and educator. Drawing on the seminal work of Edward Lazzerini, Hakan Kırıml, James Meyer, and Mustafa Tuna, among others, who have written extensively on Gasprinskii's ideas and his actions in promoting new-method schooling, ${ }^{3}$ here

1 Among the latest events related to the topic is a round table hosted by the Kazan State University, cf. L. Almazova, "Nezatikhaiushchie spory vokrug fenomena tatarskogo dzhadidizma." Islamology 10/2 (2020): 180-87.

2 To name just a few: M. Kemper, Sufis und Gelehrte in Tatarien und Baschkirien, 1789-1889: Der islamische Diskurs unter russischer Herrschaft (Berlin: Klaus Schwarz Verlag, 1998); A.J. Frank, Bukhara and the Muslims of Russia: Sufism, Education, and the Paradox of Islamic Prestige (Leiden: Brill, 2012); D. DeWeese, "It Was a Dark and Stagnant Night ('til the Jadids Brought the Light): Clichés, Biases, and False Dichotomies in the Intellectual History of Central Asia." Journal of the Economic and Social History of the Orient 59/1-2 (2016): 37-92; P. Sartori, "Ijtihād in Bukhara: Central Asian Jadidism and Local Genealogies of Cultural Change." Journal of the Economic and Social History of the Orient 59/1-2 (2016): 193-236; D. Ross, Tatar Empire: Kazan's Muslims and the Making of Imperial Russia (Bloomington, IN: Indiana University Press, 2020).

3 Including but not limited to: E.J. Lazzerini, "Ismail Bey Gasprinskii and Muslim Modernism in Russia: 1878-1914" (PhD dissertation, University of Washington, 1973); H. Kırıml, National Movements and National Identity among the Crimean Tatars (1905-1916) (Leiden: Brill, 1996); J.H. Meyer, Turks Across Empires: Marketing Muslim Identity in the Russian-Ottoman 
I propose adopting a somewhat different lens for analysing his contribution to the advancement of Muslims' position in the Russian empire. In this paper, I suggest viewing Gasprinskii not (so much) as a mastermind behind a Tatar nation-building project or as a shaper of the Muslim public sphere through his active engagement with printed media, but as a representative of a novel, 'hybrid' kind of Muslim leadership - a type of leadership that emerged in nineteenth-century Muslim communities in Russia and elsewhere around the globe, and which initiated new modes of conversation between the coloniser and the colonised. This approach draws on the theory of cultural hybridity developed by scholars including Homi Bhabha, Stuart Hall, and Paul Gilroy, who have emphasised the interrelations and interdependence between colonial rulers and their subjects. In simple terms, their argument posits that social categories imposed on the colonised (e.g. ideas about cultural and racial superiority and inferiority) create a specific imagery, which then collides with the colonised's own perceptions of the world, resulting in 'hybrid', 'in-between' expressions of culture and belonging; these hybrid expressions, in turn, challenge the beliefs and experiences of the coloniser. ${ }^{4}$ This paper has also greatly benefited from the discussion in Hilary Kalmbach's recent monograph, where she skilfully applied the hybridity framework to analyse forms of Muslim leadership in Egypt at the turn of the twentieth century. ${ }^{5}$

The departure point for the following analysis is the premise that knowledge imported into the Russian empire from Europe was translated and applied in various ways; often in non-Muslim communities first, and later among Russia's Muslims. There were many effects of this internalisation of knowledge, among which was the creation of new hybrid individuals in Russia's Muslim societies. These hybrid individuals who later rose to become new religious intellectuals and elites had a novel kind of educational background, one that combined religious and civil expertise. This unique background, in turn, enabled these Muslims to operate across boundaries and establish themselves as both social (community) and religious leaders. Importantly, this novel religious leadership was accessible and appealing to individuals without significant religious

Borderlands, 1856-1914 (Oxford: Oxford University Press, 2014); M. Tuna, Imperial Russia's Muslims: Islam, Empire and European Modernity, 1788-1914 (Cambridge: Cambridge University Press, 2015).

4 H.K. Bhabha, The Location of Culture (London: Routledge, 1994); P. Burke, Cultural Hybridity (New York, NY: John Wiley \& Sons, 2013); P. Werbner and T. Modood, Debating Cultural Hybridity: Multicultural Identities and the Politics of Anti-Racism (London: Zed Books, 2015).

5 H. Kalmbach, Islamic Knowledge and the Making of Modern Egypt (Cambridge: Cambridge University Press, 2020). 
education within Muslim communities, as well as to figures from the colonial administration.

Gasprinskii was precisely this kind of hybrid, as he had a foothold on both sides of a number of social boundaries-he was both Muslim and European, both Russian and non-Russian - and thus embodied characteristics of more than one socio-cultural group at the same time. As Kalmbach posits, this 'in-between' position and constant straddling of boundaries "can result in hybridity that is socioculturally visible or invisible, though $[. .$.$] the focus to date$ has been almost entirely on the former". ${ }^{6}$ Gasprinskii, more fluent in Russian and French than in Persian and Arabic, positioned himself and hoped to be recognised by his interlocutors as a broker between the 'Russian' and 'Islamic' worlds-cognitive constructs consolidated in the run of the nineteenth century. This hybridity, as suggested above, represented an inherent challenge to the status quo: by crossing linguistic and discursive boundaries, personalities like Gasprinskii eventually blurred the demarcation lines between what did and did not belong to a given group. As a Muslim thinker with religious-secular training received both in Russia and in Europe, in his numerous publications he absorbed, reinterpreted, and eventually combined local understandings of Russianness with elements from broadly circulating transnational Islamic and European cultural debates.

The agency exercised by individuals like Gasprinskii, who crossed boundaries and consciously hybridised cultural codes, was a major engine that drove social change in Muslim communities not only under Russian but also British and French colonial rule, creating modernities that were unique to the regions in question. However, unlike in other contexts, the case of Russia's Muslims was exceptional in the sense that here, the coloniser's culture also maintained an uneasy and unequal standing vis-à-vis Western Europe; thus, many of the social categories imposed on Russia's Muslims were in themselves already 'hybrid', having emerged from the 'encounter' between Russian and European cultural codes. To reveal this multi-layeredness and multidimensionality of cultural spaces in which Muslim leaders operated in Russia at the turn of the twentieth century, here I propose to unpack the loaded concept of Islamic Reformation. ${ }^{7}$

6 Ibid.: 25 .

7 Throughout this paper, the term 'Reformation' (capitalised) refers to the movement within Western Christianity in sixteenth-century Europe; whereas the lower-case 'reformation' denotes a general process of reforming an institution or practice. Where the term appears in a quotation, the orthography of the source text is retained. 
The concept of Islamic Reformation, advocated in fin-de-siècle discourses in Russian as well as Ottoman, Indian, Egyptian, and Iranian contexts, ${ }^{8}$ encapsulated Muslims' aspirations, endorsed also by non-Muslims, for fundamental transformations in the Islamic world akin to the revolutionary upheaval in Christian Europe provoked by German theologian Martin Luther (1483-1546). Following Elías José Palti's observation, I argue that loaded concepts like (Islamic) Reformation do not have just a single objective meaning. Instead, each user of the concept tends to imbue it with specific, often mutually exclusive connotations. It is thus more constructive to view such concepts as "indexes of problems", ${ }^{9}$ i.e. as references to fundamental paradoxes and different understandings of, for instance, what the modernisation of a religious community should entail and what goals this project should pursue. Therefore, in this paper, I aim to go beyond the textual surface and try to recreate contexts of debate in order to penetrate the argumentative apparatus of several parties that participated in defining the concept of Islamic Reformation. That is, I seek to identify the particular set of assumptions upheld by Gasprinskii, his fellow Muslim, as well as Russian-language interlocutors regarding the need for reforms in Muslim communities. I hope to thereby shed light on blind spots that were intrinsic to all such individuals, which turned the concept of Islamic Reformation into a political one. ${ }^{10}$

To pursue this goal, this paper focuses almost exclusively on Gasprinskii's early texts (from the 188os) written in Russian, which explicitly targeted his Russian-language interlocutors: a broad and heterogenous group that included Orthodox Christian missionaries, Russian intellectual elites, political figures, and Orientalists. In order to reveal deeper layers of meanings associated with the Islamic Reformation concept that are not necessarily limited to Russia, here I juxtapose parts of Gasprinskii's work with writings by his Indian counterpart Sayyid Aḥmad Khān (d. 1898), who was, in many aspects, also Gasprinskii's source of inspiration. Such a juxtaposition helps, first, to elevate Gasprinskii from the Muslim Turkic-language milieu to which he often remains confined; but more importantly, it reveals the intricate connections and ruptures

8 Ch. Kurzman and M. Browers, "Introduction." In An Islamic Reformation? (New York, NY: Lexington Books, 2004): 1-17; Sukidi, "The Traveling Idea of Islamic Protestantism: A Study of Iranian Luthers." Islam and Christian-Muslim Relations 16/4 (2005): 401-12; M.B. Wilson, Translating the Qur'an in an Age of Nationalism: Print Culture and Modern Islam in Turkey (Oxford: Oxford University Press, 2014): 144-51. See also the special issue of Islamology 8/2 (2018).

9 E.J. Palti, "The 'Theoretical Revolution' in Intellectual History: From the History of Political Ideas to the History of Political Languages." History and Theory 53/ 3 (2014): 398.

Ibid.: 39o. 
in the meaning of the Islamic Reformation concept between the Russian and Western European (especially British) discourses on civilisation, progress, and colonialism in the nineteenth century. Tracing the connections between the seemingly distant discourses of Gasprinskii and Ahmad Khān, this paper thus seeks to show how the Islamic Reformation construct was co-opted and leveraged by colonised Muslim intellectuals not only in Russia, but also in other parts of the globe, to resist their own dehumanisation and second-class status within the colonial order.

Shaping of an Influential Hybrid

The rich body of scholarly work on this subject has led to the popular image of Gasprinskii as a path-breaker, an architect of a large-scale modernisation programme, a trans-imperial Muslim who acted as a broker between the Russian and Ottoman empires, and an advocate of grandiose pan-Turkic projects. Moving away from Gasprinskii's well-known publications in Turkic languages, here I focus exclusively on the Russian-language texts produced at the beginning of his political career, to argue that from early on, he spoke in favour of cautious reforms, siding more often with Russian conservative liberals (who, despite their political views, remained loyal to the state) than with Muslim intellectuals who, especially after 1905, assertively demanded bold reforms to secure cultural and national autonomy for Muslims in Russia. ${ }^{11}$ Thus, unlike previous work on Gasprinskii that has situated him at the centre of the Muslim reformist movement, the focus adopted here shows him rather as a representative of an emerging intermediary group centred around new civil-religious hybrid individuals who constantly crossed multiple boundaries that existed between the Muslim minority and Russian mainstream society, and in doing so, challenged them in subtle, indirect ways.

To understand Gasprinskii's evolution as a hybrid individual, it is important to revisit his upbringing. Born in 1851 to a family of a Crimean Tatar member of Russian nobility, Gasprinskii first received a traditional Muslim education in Bakhchisarai and then continued his studies at Russian military schools in Voronezh and, from 1865 to 1867 , in Moscow. His formative years

11 M. Kemper, "Muslim EuRossocentrism. Ismail Gasprinskii's 'Russian Islam' (1881)." In Eurocentrism in European History and Memory, ed. M. Brolsma, R. de Bruin, and M. Lok (Amsterdam: Amsterdam University Press, 2019): 84; also Ch. Noack, Muslimischer Nationalismus im russischen Reich: Nationsbildung und Nationalbewegung bei Tataren und Baschkiren: 1861-1917 (Stuttgart: Franz Steiner Verlag, 200o). 
coincided with a series of tectonic shifts that shook the Romanovs' empire, the most important of these being the Crimean war of $1853^{-6}$ and the Great Reforms. Growing up in 185 os Crimea, Gasprinskii witnessed and was clearly troubled by the major transformations that affected the region. Although Empress Catherine the Great adopted a tolerant stance toward Islam after she had annexed the Crimea in 1783 , her 'Greek project' of creating Christian buffer states between the Austrian and Russian empires, ${ }^{12}$ had stripped the Muslim Crimean Tatars of their means of subsistence: following the annexation, Russian settlers moved to the peninsula and seized the control over Crimean Tatar peasantry's land. The result by the mid-nineteenth century was "the continuous emigration of Crimea's Muslim population to the Ottoman lands, whereas remaining elites [...] were either impoverished or co-opted and alienated from their kin"; a situation that was only aggravated by the Crimean war. ${ }^{13}$ Gasprinskii's years of study in Moscow coincided with the era of Great Reforms and the emancipation of the serf, which increased popular participation in the political process, albeit not in the fashion Alexander II envisioned. On the one hand, a vibrant extra-parliamentary civil society emerged thanks to the developing middle class, a newly-established network of rural self-government organs (zemstvos), and the rise of journalism; on the other hand, the Great Reforms also spawned a powerful radical revolutionary movement that remained deeply unsatisfied with the ongoing transformations due to their incomplete nature. ${ }^{14}$

Challenges to the Tsarist rule came not only from the revolutionaries but also from an increasingly influential liberal wing of civil society that also saw the Great Reforms as an unfinished project; yet, despite their opposition, this group remained, by and large, loyal to the state system. While in Moscow, Gasprinskii actively cultivated connections with Russian intellectual elites. It has been suggested ${ }^{15}$ that the young Ismāîl was a frequent guest at the home of seasoned publicist Mikhail Katkov (1818-87). As the editor-in-chief of Moskovskie vedomosti (Moscow Gazette), Katkov used the outlet as a platform to advocate his ideas on national integrity and the benefits of an absolute monarchy; from the mid-186os, he actively spoke in favour of a system of

\footnotetext{
12 On the Greek project, see A. Zorin, Kormia dvuglavogo orla. Russkaia literatura i gosudarstvennaia ideologiiav Rossiiv poslednei tretiXVIII-pervoi tretiXIX veka (Moscow: NLO, 2001).

13 M. Özgür Tuna, "Gaspirali v. Il'minskii: Two Identity Projects for the Muslims of the Russian Empire." Nationalities Papers 30/2 (2002): 267.

14 A.A. Fedyashin, Liberals under Autocracy: Modernization and Civil Society in Russia, 18661904 (Madison, WI: University of Wisconsin Press, 2012): 4.

15 Lazzerini, "Ismail Bey Gasprinskii": 4.
} 
state-controlled education (with Russian as the lingua franca). ${ }^{16}$ His project of nation-building involved the creation of world-class literature in Russian, and as the chief editor of the prominent journal Russkii vestnik (Russian Bulletin), he curated the work of major writers and critics of the period, including Ivan Turgenev (1818-83), Fiodor Dostoevskii (1821-81), and Lev Tolstoi (1828-1910) ${ }^{17}$; Gasprinskii was familiar with their masterpieces. ${ }^{18}$

In 1871-4, Gasprinskii lived in Paris, but this period of his life remains poorly studied. It is known that Gasprinskii attended lectures at the Sorbonne University and worked as Ivan Turgenev's secretary. ${ }^{19}$ After Paris, Gasprinskii moved to Istanbul. During his time there (1874-5) he witnessed major changes taking place in the Ottoman empire, as the country gradually transitioned from the ideas of Ottomanism dominant in the Tanzimat period (1839-76) to the ideology of Pan-Islamism, which became especially noticeable during the reign of the Sultan Abdul Hamid II (1876-1908). In Istanbul, or perhaps already in Paris, Gasprinskii cultivated contacts with the secret society of the Young Ottomans, whose liberal-reformist views evidently had a strong impact on Gasprinskii's thinking. ${ }^{20}$

Back in Russia, Gasprinskii witnessed and later benefited from the proliferation and growing influence of printed media. It was precisely the absence of an accessible and open political sphere that magnified the impact of Russian newspapers and journals, which boomed after Nicholas I's death and the closure of the Buturlin Censorship Committee in $1855 .{ }^{21}$ Gasprinskii entered the unfolding public debates first by publishing in Russian-language outlets and later by starting his own, equally influential bilingual newspaper Tarjuman/

16 A. Renner, “Defining a Russian Nation: Mikhail Katkov and the 'Invention' of National Politics." The Slavonic and East European Review 81/4 (2003): 659-82.

17 A. Vdovin and A. Fedotov, "Kak izuchat' Katkova segodnia." Novoe literaturnoe obozrenie 153 (2018), https://www.nlobooks.ru/magazines/novoe_literaturnoe_obozrenie/153/ article $/ 20190 /$.

18 Gasprinskii translated and/or published translations into Crimean Tatar of works by prominent Russian-language writers and poets, including Lev Tolstoi, Aleksandr Pushkin, and Maksim Gor'kii, among others; cf. Z. Isliamova, "Katalog izdanii Ismaila Gasprinskogo v fondakh Respublikanskoi krymskotatarskoi biblioteki." Krymskii arkhiv, 2/21 (2016): $3^{-16 .}$

19 See a discussion in N. Tikhonova, "Rol' krymskotatarskoi gazety 'Perevodchik-Terdzhiman' v etnokul'turnom i politicheskom diskurse v Rossii v 1880-1910-e gg." (PhD dissertation, St Petersburg State University, 2019): 3 o.

20 Ibid.: $32-3$.

21 Ch.A. Ruud, Fighting Words: Imperial Censorship and the Russian Press, 1804-1906 (Toronto: University of Toronto Press, 20o9). On the Buturlin Committee, see esp. pp. 83-96. 
Perevodchik (The Translator, 1883-1914). Of his early Russian-language publications, Russkoe musul'manstvo (Russian Muslimhood, 1881) is probably the most well-known. Due to its rich and controversial content, Russkoe musul'manstvo has been analysed mostly as a standalone paper, ${ }^{22}$ though it clearly resonates with a number of other publications, namely A. Devlet-Kil'deev's brochure on the Prophet Muhammad (1881), the publications on Islam of a certain Murza Alim in the Sankt-Peterburgskie vedomosti (St. Petersburg Gazette, 1882), 'Ațā’ullāh Baiazitov's objections to the French Orientalist and sociologist of culture Ernest Renan ${ }^{23}$ (1883), and a piece by a certain "Muslim" (Musul'manin) on Islam and rationalism $(1883) \cdot{ }^{24}$ All these essays, written for a Russian-speaking audience, methodically portrayed Islam as a religion compatible with rational thought and a modern lifestyle, thereby attempting to challenge the popular perception of Russia's Muslims as stagnant and backward citizens of the empire.

22 M. Kemper, "Ismail Gasprinskij's 'Russisches Muslimentum' (1881)." Frankfurter Zeitschrift für islamisch-theologische Studien 4 (2018): 125-38; also Kemper, "Muslim EuRossocentrism."

23 Renan's racist arguments claiming that Semites are not capable of rational thinking initially triggered a response from Sayyid Jamāl al-Dīn al-Afghānī (1838-97); the Renan/ al-Afghānī debate also made its way into the Arabic, Turkish, and Farsi press. See M. Kohn, "Afghānī on Empire, Islam, and Civilization." Political Theory 37/3 (2009): 398-422; M. Guida, "Al-Afghānī and Namık Kemal's Replies to Ernest Renan: Two Anti-Westernist Works in the Formative Stage of Islamist Thought." Turkish Journal of Politics 2/2 (2011): 57-70.

24 A. Baiazitov, Vozrazhenie na rech' Ernesta Renana. Islam i nauka (Saint Petersburg: Tipografiia A.S. Suvorina, 1883); A. Devlet-Kil'deev, Magomet kak prorok (Saint Petersburg: Tipografiia A.S. Suvorina, 1881); Ismail Bey Gasprinskii, Russkoe musul'manstvo. Mysli, zametki i nabliudeniia (Simferopol, 1881); Murza Alim, "Islam i magometanstvo." SanktPeterburgskie Vedomosti 180 (6 July 1882) and 188 (14 July 1882); Musul'manin, "Musul'manstvo i ratsionalizm." Vostochnoe obozrenie 24 (1883) For a discussion of the content of these papers, see M.A. Batunskii, "Pravoslavie, islam i problemy modernizatsii v Rossii na rubezhe XIX-XX vekov." Obshchestvennye nauki i sovremennost' 2 (1996): 81-9o; O. Bessmertnaia, "Tol'ko li marginalii? Tri epizoda s 'musul'manskim russkim iazykom' v pozdnei Rossiiskoi imperii." Islamology 7/1 (2017): 140-79; Bessmertnaia, "Ponimanie istorii i identichnost' avtora v vozrazheniiakh Ataully Baiazitova Ernestu Renanu." Islamology 9/1-2 (2019): 54-82. On other Russian-language work written by Muslims around the same period, see R.A. Nabiev and A.A. Gafarov, "Problemy religioznoi tolerantnosti $\mathrm{v}$ trudakh musul'manskikh modernistov vo vtoroi polovine XIX-nachale XX v." Uchenye zapiski Kazanskogo universiteta 153/3 (2011): 120-30. 
'Ațā̄ullāh Baiazitov 25 (1846-1911) and A. Devlet-Kil'deev ${ }^{26}$ were real historical figures, though their authorship of the respective pieces is still debatable. ${ }^{27}$ "Murza Alim" and "The Muslim" are, by contrast, pseudonyms that led some to suspect the presence of a prestigious figure behind these names. Analysing Murza Alim's writing style, the prominent Orthodox Christian missionary Nikolai Il'minskii (1822-91) suggested that the newspaper publications were authored by Baiazitov. ${ }^{28}$ Scholar Olga Bessmertnaia, in her recent paper, endorses Il'minskii's idea. ${ }^{29}$ However, Tat'iana Kotiukova and Igor' Alekseev, who studied private letters purportedly from Murza Alim to Russian Orientalist Nikolai Ostroumov (1846-1930), have suggested that the letters could have been authored by Gasprinskii. ${ }^{30}$ On closer examination, these letters indeed resonate strongly with some of Gasprinskii's most controversial standpoints advanced in his Russkoe musul'manstvo essay. ${ }^{31}$ In fact, Gasprinskii had a

25 Baiazitov was also a hybrid figure: he fulfilled a double role by serving his Tatar community in St. Petersburg as an imām and the Russian state as a military Muslim "cleric"; cf. A. von Kügelgen, "'Progressiver Islam' im Ausgehenden Zarenreich: Das Plädoyer des St. Petersburger Imams und Regierungsbeamten Ataulla Bajazitov (1846-1911) für die Partizipation der Muslime an der modernen Zivilisation." Asiatische Studien/Études Asiatiques 67(3): 927-64. Gasprinskii must have been familiar with Baiazitov's objections to Renan, as he and Baiazitov were acquainted and maintained regular correspondence. This correspondence, for instance, enabled Tarjuman/Perevodchik to closely follow and report on the construction of the St. Petersburg mosque initiated by Baiazitov in the 188os; cf. S. Seitmemetova, "Iz lichnoi biblioteki Ismaila Gasprinskogo." Bakhchisaraiskii muzeizapovednik, https://handvorec.ru/novosti/iz-lichnoj-biblioteki-ismaila-gasprinskogo/.

26 Gasprinskii cooperated with A. Devlet-Kil'deev prior to the successful launch of his Tarjuman/Perevodchik newspaper; see an editorial note by Gasprinskii published in Shafaq (1881), reprinted in I. Gasprinskii, Polnoe sobranie sochinenii. Ranniaia publitsistika 1879-1886. Vol. 2, ed. R. Khakimov (Kazan, Simferopol: Institut Istorii im. Sh. Mardzhani, 2017): 55 . The scarce information available on A. Devlet-Kil'deev suggests that he was probably a member of the nobility and worked as a journalist for Ufimskie gubernskie vedomosti (Ufa Province Gazette); cf. "Devlet-Kil'deev." In Kritiko-biograficheskii slovar' russkikh pisatelei i uchenykh, ed. S.A. Vengerov (St. Petersburg: Semenovskaia tipolitografiia, 1889-1904). Online https://dic.academic.ru/dic.nsf/enc_biography/Девлет.

27 E.g. R. Bekkin, "Vasilii Velichko i ego proekt 'Ataulla Baiazitov—russkii publitsist'." Bel'skie prostory 10 (2016): 152-6o.

28 Bessmertnaia, "Ponimanie istorii": 59.

29 Ibid.: 6o.

30 T. Kotiukova and I. Alekseev, "Pis'ma Murzy Alima i Gasprinskogo k N.P.Ostroumovu iz lichnogo arkhiva N.I.Il'minskogo." Conference paper presented at I Bakhchisaraiskie nauchnye chteniia pamiati I. Gasprinskogo, Bakhchisarai, 5-6 April 2012.

31 For instance, like Gasprinskii, Murza Alim maintains a Tatarocentrist position and suggests that, in Russia's "movement to the East", the interests of the Russian authorities (establishing control over territories) and those of Tatars ("civilising" the local Muslim population) coincide: "[As] much as I could notice from the content of your articles, you 
whole range of pen names, including "Little Mullā" (Malen'kii mulla), "The Tatar" (Tatarin), "An Old Man" (Qart aga), and probably also "The Muslim" (Musul'manin), ${ }^{32}$ as the 1883 newspaper article under this name also follows Gasprinskii's arguments used to prove the rationality of Islam. Gasprinskii seems to have used pen names when sending out trial balloons and testing the public response to his often provocative ideas without risking his reputation. Moreover, articulating similar ideas under pseudonyms in different media outlets with varying reach allowed Gasprinskii to address several, not necessarily overlapping audiences and to create an impression of broader support for these ideas among progressive Muslim elites. In light of this, in this paper I therefore treat Murza Alim as one of Gasprinskii's alter egos, and will thus also include Murza Alim's newspaper articles and letters to Ostroumov as part of Gasprinskii's discourse.

It is in the Sankt-Peterburgskie vedomosti article from 1882 that we find probably one of the earliest notes on the Protestant Reformation as a point of reference for the fortunes of Russian Islam:

We are standing on the eve of the great religious reformation in the Muslim world, which will have the same influence on the further development of Muslims as Luther's Reformation had on the Old Catholic world; and this [Islamic] reformation will inevitably revive Islam, temporarily in slumber, to new life and activity. The Old Believers [starovery] and Old Ritualists [staroobriadtsy] of this [Islamic] religious form of monotheism will have no influence on the mental development of future

want, like me, to promote, as much as possible, the cultural progress of the Mohammedan inhabitants of Russia, and to strengthen [the empire's] Asian possessions." See Murza Alim, "Letter to N. Ostroumov (Bakhchisarai, 7 May 1883)." The National Archive of the Republic of Tatarstan, 968-1-72: fol. 9 r-v. Compare with the analysis of Gasprinskii's standpoints in Kemper, "Muslim EuRossocentrism."

$3^{2}$ Scholar Ismail Kerimov points to the parallels between ideas expressed by Murza Alim in his letters to Ostroumov and the thoughts articulated by the fictional character Mullā 'Abbās, the protagonist of Gasprinskii's novel Letters from Europe (in the original: Frengistan Mektupları); cf. I. Kerimov, Slovar' trudnykh slov krymskotatarskogo iazyka (Simferopol: Tavrida, 2006): 172-74. On the novel, first published in the pages of Tarjuman/Perevodchik in 1887-9, see Tuna, Imperial Russia's Muslims: 150-54. 
Muslim generations; [the former] will be absorbed by [the latter] in an unequal struggle for existence. ${ }^{33}$

In the same article, Gasprinskii presents Russia's Muslims as carriers of the baton passed on by Indian Muslim reformists; he prophesies that "if the wave of religious reformation coming from India touches Russian Mohammedanism, then a religious schism will inevitably occur among its members". ${ }^{34}$ Gasprinskii directly refers to Sayyid Aḥmad Khān, depicting him as the leading figure behind the powerful Muslim reformist movement in India. A quick comparison of the two figures reveals many striking parallels. Aḥmad Khān was a renowned educational activist and religious thinker who sought to improve relations between the British colonial government and India's Muslims following the 1857-8 Indian Rebellion against the rule of British East India. Ahmad Khān paid a visit to England in 1869-70; following the trip, he founded a local Muslim periodical to disseminate reformist ideas. Commenting on this breakthrough, he argued that "India needs not only a [Muslim] Steele or an Addison" - referring to Richard Steele (1672-1729) and Joseph Addison (16721719), founders of the influential English Tatler (1709) and Spectator (1711-2) publications respectively_- "but also, primarily, [India needs] a Luther". 35

References to British India were common among Russian administrators who sought to benefit from the experience of other colonial powers in ruling the Muslim subject: in particular, the policy of establishing Russia's protectorates of Bukhara and Khiva in Central Asia was inspired by British treaties with various princely states in India. ${ }^{36}$ Gasprinskii may have familiarised himself with Aḥmad Khān's work via such Russian sources or foreign-language literature during his stays in Paris and Istanbul. Aḥmad Khān attracted much attention especially in the 1870s, when Sultan Abdul Hamid II stressed his claims to the title of the Muslim caliph and a considerable portion of Muslims in India recognised him as their leader. For a while, Britain encouraged this recognition, ${ }^{37}$

33 Murza Alim, "Islam i magometanstvo." 6 July 1882.

34 Ibid. See also Gasprinskii, Russkoe musul'manstvo: 43.

35 Aḥmad Khān's writing from 11 March 1872, as quoted in M. Siddiqi, "Religious Thought of Sir Sayyid Ahmad Khan." Islamic Studies 6/3(1967): 290-308. Though Aḥmad Khān never sought to present himself as the Indian Muslim Luther, he was portrayed as such by his contemporaries; Ch.W. Troll, Sayyid Ahmad Khan: A Reinterpretation of Muslim Theology (Noida: Vikas Publishing House, 1978): 14, 16.

36 A. Khalid, The Politics of Muslim Cultural Reform (Berkeley, CA: University of California Press, 1999); A. Morrison, "Russian Rule in Turkestan and the Example of British India, c. 1860-1917." The Slavonic and East European Review 84/4 (2006): 666-707.

37 Y.Saikia and M.R. Rahman, The Cambridge Companion to Sayyid Ahmad Khan (Cambridge, MA: Cambridge University Press, 2019): 46. 
and Ahmmad Khān, as the prominent spokesperson on behalf of the Indian Muslim community, tried to strike a balance between expressions of loyalty to the British and tributes to the caliph. ${ }^{38}$

Aḥmad Khān's seminal essay Asbab-i-bhagavat-i-Hind (English: The Causes of the Indian Revolt ${ }^{39}$ ), published in 1858, echoes Gasprinskii's Russkoe musul'manstvo in how the two men propose redesigning the forms of colonial government over the respective Muslim populations. Similar to Gasprinskii, Ahmmad Khān wrote his book in response to what he saw as pernicious theories advocated by dominant political and intellectual elites that accused Muslims of being bound by their faith to be disloyal to the authorities. Khān's main argument drew upon a reasoned sociological analysis that pointed to a lack of communication between the government and the governed as the primary cause of the latter's unruliness. Therefore, one of Aḥmad Khān's pleas was to ensure a greater native representation in the East India Company administration. ${ }^{40}$ Gasprinskii, in turn, suggested in his essay a new concept, russkoe musul'manstvo. According to Michael Kemper, he used this concept not in the sense of Russifying the religion of Islam, but rather as an ethnographic reality (the religion and the very phenomenon of Muslim communities that happened to live under the Russian rule); Gasprinskii acknowledged that russkoe musul'manstvo emerged as a product of Russia's imperial expansion but rejected the passive role that Muslims were expected to occupy. Emphasising the inconsistencies in how the Russian state treated its Muslim subjects, Gasprinskii suggested a rapprochement; in his view, in order to secure Muslims' loyalty to the Tsar one did not need to look for flaws in their religious teaching but combat their ignorance and self-isolation by providing means for education and cultural development. ${ }^{41}$

What Gasprinskii and Aḥmad Khān were struggling to challenge through their respective essays and later work was the distance between the ruler and the ruled. In a discussion that began with Edward Said's seminal work Orientalism (1978), scholars have investigated how Europe, including Russia, understood itself through its colonies, be they somewhere overseas or in close proximity. ${ }^{42}$ European self-understanding, as the argument goes, was firmly

38 S.T. Wasti, "Sir Syed Ahmad Khan and the Turks." Middle Eastern Studies 46/4 (2010): 529-42.

39 S.A. Khan, The Causes of the Indian Revolt (Benares: Medical Hall Press, 1873).

40 Kh. Hussain, Islam as Critique: Sayyid Ahmad Khan and the Challenge of Modernity (London: Bloomsbury Publishing, 2019): 36 .

41 Kemper, "Muslim EuRossocentrism": 86.

42 A. Etkind, Internal Colonization: Russia's Imperial Experience (Honoken, NJ: John Wiley \& Sons, 2013). 
grounded in the continuous construction and reproduction of the categories of the colonised and the coloniser, keeping them distinct and in a clearly established power relation. ${ }^{43}$ Although throughout the nineteenth century, the Russian, French, and British empires advanced a transition to a 'modern' form of colonial state, in which laws, economic practices, and languages were homogenised by state elites, the political and economic reforms did not close this gap. The idea of hastening the development of inferior and uncivilised peoples had been a dominant source of imperial legitimisation, and the elites in power were not interested in supporting the moves that could actually emancipate and empower the colonised. ${ }^{44}$

It was precisely in this context of an encounter with the Other-be it a Jewish, a Muslim or a Black Other-and the need to sustain the narrative of cultural superiority that the concept of (Protestant) Reformation acquired the particular connotation of a sign of God's favour towards Christians, which was supposed to explain the alleged supremacy of European statecraft, science and culture. ${ }^{45}$ Reformed Christianity came to be regarded as a reflective, reasonbased intellectual religious tradition embedded in Western culture, in contrast to Jewish and Islamic 'dogmatisms'. ${ }^{46}$ In the colonial context, this discursive framework bestowed legitimacy upon colonial rule to undertake a religious mission in order to help the colonised societies achieve levels of political maturity and civilisation similar to those of the coloniser. As a result, religion transformed from being part of everyday life, practically 'unnoticed' by its practitioners, to the single and most important factor in defining large groups of people both within and outside Europe. As the study of communities living across vast territories across the Middle East, North Africa, and South-East Asia intensified, European Oriental and missionary scholarship engaged in the racialisation (and exoticisation) of Muslimness, which unfolded largely between the 1820 s and 1880 os alongside the racialisation of Blackness and

43 R.G. Suny, "The Empire Strikes Out: Imperial Russia, 'National' Identity, and Theories of Empire." In A State of Nations: Empire and Nation-Making in the Age of Lenin and Stalin, ed. R.G. Suny and T. Martin (Oxford: Oxford University Press, 2001): 32.

44 Ibid.: 30-1.

45 On the evolution of the term through the work of seventeenth and eighteenth-century European literati, see J. Sheehan, The Enlightenment Bible:Translation, Scholarship, Culture (Princeton, NJ: Princeton University Press, 2013); M.C. Legaspi, The Death of Scripture and the Rise of Biblical Studies (Oxford: Oxford University Press, 2010). Specifically, on the creation of "the essential Luther", cf. A.E. Harvey, "Martin Luther in the Estimate of Modern Historians." The American Journal of Theology 22/3 (1918): 321-48.

46 S.H. Jones et al., "'That's How Muslims Are Required to View the World': Race, Culture and Belief in Non-Muslims' Descriptions of Islam and Science." The Sociological Review 67/1 (2019): 161-77. 
Asianness. ${ }^{47}$ The Crimean war and, later, the $1877-8$ Ottoman-Russian wars became crucial in mobilising these essentialised and often juxtaposed Muslim and Christian identities globally, which overshadowed a previous imperial logic that was centred on cosmopolitanism. In Cemil Aydin's words, while "Russia appealed to Orthodox Christian solidarity and the symbol of the Hagia Sophia, ruled by Muslims, [the] Ottomans called for jihad, even though their goal was to retain control over Bulgarian, Romanian, and Serbian Christian territories". ${ }^{48}$

It was in reaction to these discourses engaged in constructing globalised religious identities that Gasprinskii and Aḥmad Khān, while speaking on behalf of their respective communities, concerned themselves with Islam (or "Muslimhood") and not so much with Muslims as such. The term 'Islam', as they used it, referred to a body of practices and beliefs, or a religious-ethical system that arguably existed independently of its believers. Moreover, speaking in the language of the colonisers, these Muslim leaders assumed the role of crucial intermediaries. In their advocacy of religious reforms, Aḥmad Khān and Gasprinskii not only tapped into the coloniser's sensitivities but also voiced and translated indigenous, i.e. Islamic discourses that criticised contemporary pietists within their own societies. ${ }^{49}$

\section{Reformation as a Civilisational Project}

Like Aḥmad Khān, who emphasised Islam's true essence as necessarily 'progressive' in its orientation, ${ }^{50}$ Gasprinskii responded to accusations of Islam's inherent anti-modern nature by framing the problem as a loss of rationality rather than an intrinsic lack of it. Both men believed that Muslims lagged

47 By 'racialisation' here I understand the production of discourses that impose cultural and social taxonomies, form immutable identities, and define the limits of 'normal'. For a discussion on racial discourses targeting Muslims produced in the nineteenth century, see C. Aydin, "Imperial Paradoxes: A Caliphate for Subaltern Muslims." ReOrient 1/2 (2016): 171-91; Aydin, The Idea of the Muslim World: A Global Intellectual History (Cambridge, MA: Harvard University Press, 2017). On how some of these discourses became incorporated into nationalist ideologies in the Republic of Turkey, see M. Ergin, 'Is the Turk a White Man?': Race and Modernity in the Making of Turkish Identity (Leiden: Brill, 2016).

48 Aydin, The Idea of the Muslim World: 59-6o.

49 J. Malik, "Muslim Identities Suspended between Tradition and Modernity." Comparative Studies of South Asia, Africa and the Middle East 16/2 (1996): 3. For the Russian case, see, e.g. Kemper, Sufis und Gelehrte; for India, see F. Robinson, "Islamic Reform and Modernities in South Asia." Modern Asian Studies 42/2-3 (2008): 259-81.

$5^{\circ}$ Hussain, Islam as Critique: $54-57$. 
behind the West because they were a sad shadow of their former selves. In his argument, Gasprinskii attempted to incorporate popular discourses on the Islamic Golden Age, where the first centuries of Islam were presented as an embodiment of the transformative potential of this religion. Importantly, like some of his fellow Muslims, Gasprinskii saw this homogenised global Islamic civilisation as a beneficiary of the ancient Greek legacy; a process whereby preexisting knowledge merged with rational and humanist Islamic values and, through the Golden Age of Islam, contributed to the emergence of the modern West. ${ }^{51}$ According to Gasprinskii, it was Islam that fuelled European cultural and material advancement:

History provides much evidence that Muslims, having assimilated and further developed the civilisation of the ancients, passed it on to Europe, which inherited the knowledge of both the ancients and Muslims. It is known that the Europeans thoroughly familiarised themselves with Greek scientists' work through the Muslim [intellectual tradition]. ${ }^{52}$

Gasprinskii argues that in the first two centuries of Islam-in the age of the șahāba (Muhammad's Companions), the tābi ūn (the Successors, the generation after the șahāaba), and the tābiciu al-täbi ìn (the generation after the täbi'ün) - Islamic sciences and philosophy reached new heights. To support his claim that Islam is intrinsically compatible with rational thought, he mentions the rationalist school of the Mu'tazila and several seventh-century advocates of human free will, throwing in the names of Basran șahāā $\bar{\imath}$ Ma'bad al-Juhanī (d. 699) and tābic al-Hasan al-Bașrī (624-728). Gasprinskii sees the dispute between the Mu'tazilites and Ash'arites in the eighth to tenth centuries as an Islamic analogue of the Protestant break with the Catholic Church in the sixteenth century ${ }^{53}$; meanwhile, he compares the Mu'tazilites' persecution ${ }^{54}$ to the execution of Christian scholars accused of heresy in the Middle Ages. In falling back on the idealised image of the Islamic past, Gasprinskii adopts the prevailing opinion that the Muslim world is stagnant in the present because

$5^{1} \quad$ Ibid. Also, F. Devji, "Apologetic Modernity." Modern Intellectual History 4/1 (2007): 61-76.

$5^{2}$ I. Gasprinskii, "Islam i tsivilizatsiia." Tarjuman/Perevodchik 23 (25 June 1884), following Gasprinskii, Polnoe sobranie sochinenii: 225.

53 The comparison is curious since Gasprinskii clearly casts the Mu'tazilites in the role of Muslim 'Protestants', i.e. those who insisted on reason and a believer's free will, though historically they emerged earlier than the Ash'arites.

54 Gasprinskii remains vague here, as it is not clear whether he refers to the Muctazilite inquisition and persecution extending from $833-48$, known as milna, or to their repression thereafter by Islamic traditionalism. 
Muslims have forgotten their roots. A staunch advocate of reforming the Muslim education system, Gasprinskii saw reformed schools as an instrument for Muslims to recover this lost glorious past. ${ }^{55}$

In his editorial notes published in Tarjuman/Perevodchik, ${ }^{56}$ Gasprinskii defines 'civilisation' as an ultimate condition that enabled "a better life for a person", which could be achieved through scientific discoveries, cultural development and the improvement of living standards. ${ }^{57}$ With reference specifically to the Russian context, he tapped into the salient connotations of the term 'civilisation' derived initially from the French intellectual tradition. Transliterated into Russian, the concept came to mean 'culture' (as opposed to 'barbarism') but also maintained subtle connotations linked to the idea of the Third Estate (commoners) as a potentially revolutionary force hungry for political freedoms. ${ }^{58}$ However, at the end of the 186os, the term acquired new meanings when Nikolai Danilevskii (1822-85) developed his theory of cultural and historical types, thereby turning 'the civilisational approach' into one the most influential approaches to Russian and Slavic identity in the nineteenth century. Danilevskii's theory enjoyed popularity among a broad segment of the Russian cultural elite, and as a result, the term 'civilisation' became associated with closed and hostile cultural types that had little in common with each other. ${ }^{59}$

In his letters to Nikolai Ostroumov, a prominent missionary and inspector of schools in Turkestan, Gasprinskii echoed popular assumptions ${ }^{60}$ that

55 On similar ideas developed in the Egyptian Muslim context, see A. El Shamsy, Rediscovering the Islamic Classics: How Editors and Print Culture Transformed an Intellectual Tradition (Princeton, NJ: Princeton University Press, 2020). For similar ideas among Jewish intellectuals, also with references to the idealised image of the Protestant Reformation, see Ch. Wiese, "Let His Memory Be Holy to Us!':Jewish Interpretations of Martin Luther from the Enlightenment to the Holocaust." The Leo Baeck Institute Year Book 54/1 (2009): 93-126.

56 In particular, see I. Gasprinskii, "Islam i tsivilizatsiia." Tarjuman/Perevodchik 21 (10 June), 22 (17 June), 23 (25 June), 24 (1 July), 27 (30 July), 32 (17 September), 35 (16 October), 40 (11 November), 45 (19 December) for the year 1884, and 1 (8 January 1885).

57 I. Gasprinskii, "Islam i tsivilizatisiia." Tarjuman/Perevodchik 22 (17 June 1884).

$5^{8}$ M. Velizhev, Tsivilizatsiia, ili voina mirov (St. Petersburg: Izdatel'stvo Evropeiskogo universiteta, 2019): 83. Another, 'German' connotation of the term 'civilisation' was fortified under statesman Sergei Uvarov (1786-1855) in the early 185 os and defined the concept through enlightenment and the power of higher education (Bildung); cf. ibid.: 104. Gasprinskii, who spoke in favour of modernising existing Muslim (secondary) schools (madrasas), could therefore not fully internalise this second reading of 'civilisation'.

59 Ibid.: 103-4.

6o For instance, an influential French historian and political philosopher, François Guizot (1787-1874), in his seminal work History of Civilisation in Europe (1828), depicted Christianity as a civilisation-forming religion; for him, the externalisation of Christianity 
civilisation starts with the birth of religion initially dominated by a mystical worldview; he argued that religion and thus civilisation later transition into adulthood where reason comes to dominate. Adopting a clearly apologetic standpoint, Gasprinskii explains to Ostroumov that Muslims lag behind because of Islam's relative 'juvenility' when compared to the 'maturity' of Christianity (in fact, only European Protestantism), which has already undergone the Reformation:

I just cannot repeat [this] enough: Dear learned and unlearned [neuchennye] gentlemen, scholars of Islam, note that the teachings of the Prophet Mahomed and the Muslim [religion] are 6oo years younger than the Christian one, and therefore you [must] compare the Muslim world of the nineteenth century with the Christian [world] of the thirteenth century, and then you will have approximately similar [entities] for comparison and the right to draw scientific conclusions. ${ }^{61}$

For Gasprinskii, therefore, the current stage of Islamic civilisation corresponds to the medieval, pre-Lutheran period on the timeline of Christianity. Consequently, he concludes, Islam's rationalisation is only in its infancy, and one should give it time to come of age. Gasprinskii pushes the idea even further as he argues that, if one compares fourteenth-century AH Bukhara ${ }^{62}$ and fourteenth-century AD Italy, the former appears to be more civilised. ${ }^{63} \mathrm{He}$ thereby implicitly suggests that Islam, as a religion subsequent to Christianity,

could foster progress, when it was aligned with the rational mind and when the principles of Christian philosophy came to underlie the political ideology. Mainly thanks to Guizot, the term 'civilisation' acquired prominence in Russian intellectual thought starting from the 183os. Cf. Velizhev, Tsivilizatsiia: 9o. Moreover, Al-Afghānī, who read Guizot in Arabic translation in 1877, adopted some of the latter's ideas on aligning progress and religion; Muhammad 'Abduh (c. 1849-1905), then a disciple of Al-Afghānī and later another prominent propagator of the Islamic Reformation idea (also among the second generation of Muslim reformists in Russia), wrote a positive review of Guizot's work. Cf. N.R. Keddie, An Islamic Response to Imperialism. Political and Religious Writings of Sayyid Jamal ad-Din "al-Afghani" (Berkeley, CA: University of California Press, 1968): 391; A. Hourani, Arabic Thought in the Liberal Age 1798-1939 (Cambridge: Cambridge University Press, 1983): 114. 'Abduh's student at Al-Azhar, Tatar theologian Mūsā Jārullāh Bigi (1875-1949), proposed a similar "history of religions" in his Raḥmat-i ilāhiyyä borhānlarï (Orenburg, 1911).

61 Murza Alim, "Letter to N. Ostroumov (7 May 1883)": fol. 12r.

62 Gasprinskii despised this historically influential centre of Islamic education as the hotbed of conservative Islamic scholars. On Gasprinskii's visit to Bukhara in 1893, see E.J. Lazzerini, "From Bakhchisarai to Bukhara in 1893: Ismail Bey Gasprinskii's Journey to Central Asia." Central Asian Survey 3/4 (1984): 77-88.

63 Murza Alim, "Islam i magometanstvo." 6 July 1882. 
may possess even more unfulfilled civilisational potential. ${ }^{64}$ If we take Gasprinskii's framework of a linear progression of civilisations, his idea of early Muslims' scientific successes implies that the very emergence of Islam constitutes humanity's first moment of transitioning to modernity, which was followed by the Protestant Reformation many centuries later. If the Reformation is understood as the ultimate freedom of the human mind and alignment of religion with sciences, then Gasprinskii (similar to some other Muslim proponents of religious reform, as well as to Russian conservative forces) implicitly rejects the interpretation of post-Reformation European civilisation as something singular, unique and/or with roots solely on the European continent. Gasprinskii is cautious about adopting any strong positions; instead, he manoeuvres between apologetic stances confirming that Islam stagnates and arguments in favour of viewing the Islamic Golden Age as the basis of Western civilisation (which he indirectly suggests could also include the Russian empire). A clear benefit of this half-apologetic, half-defiant rhetoric is that it further hollows out the key European categories of progress, civilisation, and rationalism that, placed in the Russian context, had already been functioning as hybrid concepts that left room for alternative ways of defining modernity. Such a strategy made the Reformation concept in Gasprinskii's texts extremely fluid and enabled Russian elites, busy advocating a range of nation-building projects, to read their preferred connotations into it.

On Russia's Sonderweg

Russia's own insecure European identity imparted a special significance to its standing vis-à-vis the 'East' and, in the run of the nineteenth century, inspired major revisions of the dominant narratives of Russian history; some of these attempts curiously made Russian identity more inclusive of the empire's Muslims. ${ }^{65}$ Particularly from the second half of the nineteenth century, with

64 On comparable strategies employed by Indian Muslim reformists, see Devji, "Apologetic Modernity."

65 The uniqueness of Russian culture was explained not only through the combination of elements but also through its historical roots. In the 1870s-189os, for instance, proSlavophile intellectuals such as Nikolai Danilevskii, Fiodor Dostoevskii and Vladimir Lamanskii suggested rethinking the previously negative image of Turan. According to S. Gorshenina, "in the Russian version of the Aryan myth, Russia appeared as the direct successor of the first Indo-Persian Aryans, as well as the Sarmatians and Scythians [...]. In this context, the national diversity of the Middle World, in which the Aryans, primarily the Slavs, coexisted with the Turanians (from the Hungarians to the Kazakhs), began to be perceived as a considerable dignity, and they began to oppose it to the uniformity of 
the rise of the specialised academic field of Oriental studies, several groups of 'experts' - academic Orientalists, Christian missionaries, government officials, and Russian literati-actively engaged in the study of Russia's Orient. ${ }^{66}$ On the one hand, some Orthodox missionaries initiated projects that were more nuanced than the earlier practices of forced Christianisation, such as the promotion of native teachers and clergy among non-Russians; on the other hand, the translation of the Qur'ann from Arabic into Russian (1877/8) equipped others with new means for zealous anti-Islamic scholarship. ${ }^{67}$ Meanwhile, secular trends within Russian historiographical thought sought to comprehend the interaction of Christianity and Islam on Russian soil no longer as simply an opposition, but rather as a unity of opposites. Growing criticism of Russian imperialism manifested itself in a liberal press that, for instance, defied forceful Christianisation, as well as in popular Russian-language literary works (e.g., Lev Tolstoi's famous condemnation of Russian imperial policies in the North Caucasus in his story of Hajji Murat, completed in 1904). ${ }^{68}$

Entering the Russian-language public sphere in the early 188os, Gasprinskii could not help but dive into discussions related to various nation-building projects. If in the 1840s-70s the concept of 'nation' was used mainly by Western-oriented Russian liberals, from the 188 os it became practically a buzzword and was consequently also contested by conservative forces, who interpreted it in increasingly authoritarian and racial terms. ${ }^{69}$ Gasprinskii's use of Reformation imagery is strategic, for in the Russian-language cultural sphere, references to Luther were not so much associated with changes in church order as they instead symbolised a process of nation-building through standardisation of language, culture, education and religion (following the 'successful' German case). In its broadest sense, the concept of Reformation

"Romano-Germanic" Europe. This theory was a mirror image of the European idea that Europe is fantastically rich in its natural characteristics, while the rest of the world is poor and monotonous." Cf. S. Gorshenina, Izobretenie kontsepta Srednei/Tsentral'noi Azii (Washington, DC: Central Asia Program, 2019): 67-68.

66 V. Tolz, Russia's Own Orient: The Politics of Identity and Oriental Studies in the Late Imperial and Early Soviet Periods (Oxford: Oxford University Press, 2011).

67 P.W. Werth, At the Margins of Orthodoxy: Mission, Governance, and Confessional Politics in Russia's Volga-Kama Region, 1827-1905 (Ithaca, NY: Cornell University Press, 2002); R. Geraci, Window on the East: National and Imperial Identities in Late Tsarist Russia (Ithaca, NY: Cornell University Press, 2001).

68 Batunskii, "Pravoslavie, islam i problemy modernizatsii": 81-82.

69 A. Miller, Natsiia, ili mogushchestvo mifa (St. Petersburg: Izdatel'stvo Evropeiskogo universiteta, 2016). 
denoted democratisation of religion and accessibility of the Scripture to ordinary believers without the need for intermediaries. ${ }^{70}$

The Russian elites engaged in a difficult task of defining what constituted the national core and consequently downplaying (ideally eradicating) traces of 'inferior' cultures. Against the background of defining and forging a national core, both Western-oriented (democratic and socialist-minded) intelligentsia and conservative-thinking circles reflected on how to overcome two major divides: 1) the divide between the peasantry and educated society, which not only did not close after the Great Reforms but, on the contrary, became even more aggravated; and 2) the divide between the dominant nationality of the empire and the indigenous, non-Russian population. The two divides were comprehended, especially by Russian conservative elites, in very similar terms. What many Russian Orientalists attributed to the non-Russian minorities was similar to what Slavophiles proposed in relation to the Russian peasantry in the 186os: that the spread of progressive views among them would be a panacea for the evils of the existing order. ${ }^{71}$

Despite Gasprinskii's open favouring of European scholarship and material progress, ideologically speaking he did not uncritically endorse the European civilisational project. He could probably best be described as a loyalist: while pushing forward educational projects and advocating Muslims' participation in the public sphere, Gasprinskii tactically shared the views of Russian conservative liberals who spoke in favour of a strong monarchy and against socialist projects. In particular, he often sided with the Slavophile circles: his 1881 essay includes flattering notes about the unique Russian national character, Russian religiosity, and Russia's historical mission as an imperial power ${ }^{72}$; while in his Turkish-language essay of 1884, he openly endorses the Slavophiles' argument of Russia's civilisational Sonderweg: "If Russian pan-Slavists assert that European civilisation does not suit the Russian world, then maybe the Muslim world should [also] choose an independent path?"73 In fact, Gasprinskii treats

$70 \quad$ A. Nikitin, "Russkie, slavianofily i nemetskoe liuteranstvo." Nachalo 5 (1997): https://slovo -bogoslova.ru/nachalo/russkie-slavyanofily-i-nemeckoe-lyuter/. Such ideas were articulated also by Lev Tolstoi, see I. Berlin, Istoriia svobody. Rossiia (Moscow: NLO, 2001): 291-6. Curiously, very similar discourses also existed in nineteenth-century Norway, which also arguably did not complete the Reformation process, see A. Aschim, "Luther and Norwegian Nation-Building." Nordlit 43 (2019): 127-41.

71 In an insightful book Internal Colonization, Etkind argues that Russian Orientalism was directed not so much at overseas colonies but at its own people, and the discursive infantilisation thus concerned not only Russia's Muslims but also its peasants.

72 Kemper, "Muslim EuRossocentrism."

73 I. Gasprinskii, Avrupa medeniyetine bir nazar-i muvazene (Istanbul, 1884), following Gasprinskii, Polnoe sobranie sochinenii: 8 o. 
the Slavophile movement as the core of Pan-Slavism and, consequently, juxtaposes the 'Islamic' (or specifically Pan-Turkic) and the 'Slavic' (Pan-Slavic) worlds as comparable entities: for him, both draw on a unifying religion, both have the potential to develop a lingua franca to unite dispersed ethnic groups, and, importantly, both maintain unique cultural characteristics that place them in a complex relationship of tension and mutual benefit with Western Europe.

Gasprinskii's reference to the Protestant Reformation ("Luther's" Reformation), presented above, occurs together with his reference to Old Believers (starovery) and Old Ritualists (staroobriadtsy). In making these allusions, Gasprinskii draws attention to a key set of events in the history of Orthodox Christianity, namely, the reforms of Patriarch Nikon of Moscow undertaken between 1652 and 1666, whereby Old Believers, who opposed Nikon's reforms, were anathematised and suppressed with the support of Muscovite state power. The strategic move of evoking the Orthodox Christian past helps Gasprinskii to 'domesticate' an element of Western European history that might otherwise seem 'foreign'; by doing so, he also touches a nerve with his Russian readers. The 1870 s witnessed an upsurge in public interest regarding the seventeenth-century schism and Old Belief, ${ }^{74}$ for, in earlier decades, this topic was largely forbidden by censorship. The last years of Nicholas I's reign were marked by a tightening of the policies towards the Old Believers and the introduction of Dmitrii Bibikov's (1792-1870) system that aimed to forcibly convert them to the state church. ${ }^{75}$ For many Slavophiles, Old Believers embodied the ignorant, dark, simple Russian people who required education (although, for some, the Old Believers were also simultaneously an example of the true 'Russian spirit' unspoiled by modern developments). ${ }^{76}$ It is important to note here that Russia's Jews constituted another contested group alongside Muslims and Old Believers, and, as the discussion below shows, Gasprinskii tapped into the discourses on the 'Jewish question' too. While the messianic and sinister life force supposedly inherent in the Jewish people attracted an Orientalist kind of attention, the Jews too were struggling between maintaining their separate way of life on the one hand (risking accusations of rigidity and backwardness), and entering into the mainstream on the other (only to be labelled as

74 A. Dmitriev, "Preodolenie 'veroispovednoi ksenofobii': tema staroobriadchestva v russkoi literature 1870-1880-kh gg." Vestnik RKHGA 13/4 (2012): 180-89.

75 Th. Marsden, The Crisis of Religious Toleration in Imperial Russia: Bibikov's System for the Old Believers, 1841-1855 (Oxford: Oxford University Press, 2015).

76 See, for instance, E. Krevsky, "The Scar of the Schism: The Image of Old Believers in Late Nineteenth-Century Russian Literature." Historical Papers (1999), http://pi.library.yorku .ca/ojs/index.php/historicalpapers/article/view/39396. 
Westernisers that arguably threatened the national, 'Eastern' cohesion of the Russian people). ${ }^{77}$

By drawing parallels between Russia's Muslims and the Old Believers, Gasprinskii sought to challenge the perception dominant among the Russian elites who viewed Muslims as a culturally 'foreign' entity that required a different approach. The advancement of Muslims, he argued, could and should be achieved by the same means that were used with regard to the Old Believers: innovation in education (i.e. introducing secular subjects and modern methods of teaching). This rhetorical move could have been part of Gasprinskii's discourse aimed at convincing high-ranking Russian officials that his new method schools had the potential of bringing major change into Muslim communities.

Gasprinskii thus suggested measuring civilisation and Europeanness in terms of knowledge and modern sciences-that is, not in terms of inborn qualities of the 'tribes', but in terms of acquirable characteristics ${ }^{78}$-a point of view acceptable also to his Russian interlocutors. For Gasprinskii, the focus on secular education was the way not only to strip Muslim 'ulama $\bar{a}$ ' of their powers, but also to take the wind out of the sails of the Christian missionaries, who promoted Orthodox Christian schooling among Russia's inorodtsy (lit. 'people of alien tribes'). Gasprinskii implied, in fact, that not only Russia's Islam but also the Russian Orthodox Church required transformation. He wondered if "the ignorance of some Russian Mahommedans who reject secular knowledge is the consequence of [the Islamic system of thought] or of neighbouring Orthodoxy?"79 Gasprinskii thus played on the increasingly weakening position of the Church in Russian educated society of the time: the Slavophiles and their followers, aware of this decline in power, sought to reformulate societal roles of the Church and its relationship with the state. In particular, they stressed the importance of Orthodox Christian values and sobornost' (the idea of the divine grace residing within the communion of the Church) as defining features of Orthodox societies and advocated freeing the Church from the authority of the state. ${ }^{80}$

In general, then, Gasprinskii shared the Slavophiles' perspective on Russia's cultural uniqueness, understood in dialogue with the West: for Russian

77 H. Murav, Identity Theft: The Jew in Imperial Russia and the Case of Avraam Uri Kovner (Stanford: Stanford University Press, 2003).

78 Kemper, "Muslim EuRossocentrism": 92.

79 Murza Alim, "Letter to N. Ostroumov (St. Petersburg, 24 April 1883)." The National Archive of the Republic of Tatarstan, 968-1-72: fol. 15 r.

80 S. Rabow-Edling, Slavophile Thought and the Politics of Cultural Nationalism (Albany, NY: SUNY Press, 2012): 120-21. 
conservative forces, the nation was a provider of national form for universal human values, which made it possible for Russia to contribute something original to humanity while preserving its unique character. It was a conscious intellectual project that sought to stir the moral regeneration of the national community through the principles of the Orthodox Church and the customs of Christian people. Gasprinskii also endorsed the Slavophiles' emphasis on interpreting religion in increasingly national terms. His very calls for "Russian Muslimhood" signalled his support for the transition from purely religious to nationally-conscious (if not patriotic) religious identity. This emphasis on national culture enabled Gasprinskii to also confront his Russian interlocutors' fears of Pan-Islamism as representing a threat to the integrity of the Russian empire. He depicted the Tatars as a model of this loyal 'russkii' Muslim community: a "Muslim minority whose Islam is reduced to the ritual, whose military prowess is fully at the disposal of the state, and who are completely integrated into non-Muslim society". ${ }^{81}$

The new synthesis pursued by the Slavophiles - that is, a combination of the traditional (religion) and the modern (secular education) order $^{82}$ - provided space for maintaining religion as a basis of community; this platform also enabled Muslim hybrid individuals like Gasprinskii to undertake modernisation projects with support from Russian elites but without renouncing their Muslim religious identity (or at least, not immediately). The trade-off for this freedom was the necessary change in roles which Islam played in the public life: within this new synthesis Islam had to approximate Orthodox Christianity to equally become the essence of the unique 'russkii' civilisation.

\section{$5 \quad$ From Hybridity to Convergence}

In trying to bridge the distance between the colonisers and the colonised and blur the difference between the two, both Gasprinskii and Ahmad Khān focused on what they saw as the very core of the European (including Russian) cultural code: the Bible. Following the Protestant Reformation, vernacularisation of the Bible engendered new interpretive modes, and as a result, it became increasingly seen as a contingent textual artefact rather than as revealed Scripture, thus available for interpretation by non-theologians too; the text (particularly the New Testament) was released from exclusive precincts of exegesis and

81 Kemper, "Muslim EuRossocentrism": 95.

82 A. Valitskii, Vkrugu konservativnoi utopii. Struktura imetamorfozy russkogo slavianofil'stva (Moscow: NLO, 2019). 
placed in the heart of Western civilisation to serve as a civilisational and ethical framework. ${ }^{83}$ Both Gasprinskii and Aḥmad Khān sought rapprochement between the Bible and the Qurān, which they constructed as the Bible's equal counterpart in the Islamic world, on ethical (Gasprinskii) and theological (Aḥmad Khān) grounds. Their aim was to prove the inherent compatibility and, eventually, equality between the Christian rulers and their Muslim subjects. Aḥmad Khān, in particular, viewed the Bible as being of special revealed nature (contrary to the mainstream understanding of the tahriff doctrine) and pertinent to the interpretation of the Qur'ān. ${ }^{84}$ Relying on language analysis methods, he produced a textual commentary on relevant portions of the Old and New Testaments, in which he contested the conventional interpretations of both the Bible and the Qurān. ${ }^{85}$

For Gasprinskii, Christian Europe had the upper hand because the New Testament did not come as an ordinance or a direct message from God: both Islam and Judaism were in stagnation because they dealt with direct revelations, a hurdle that prevented Muslims and Jews from freeing their minds and abandoning the constraints of continued exegesis:

Unlike Moses and Mahomed, Jesus Christ did not leave behind a book written in the name of God, and in this way [He] freed Christian peoples' thought from any subordination to authorities, with the exception of the authority of reason. The absence of such a book is, in my opinion, the only reason for the cultural progress of the Christian ${ }^{86}$ peoples! ${ }^{87}$

Gasprinskii thus saw a historicised reading of the Qurān as a precondition for Muslim emancipation, freeing Muslim societies from the burden of forever reinterpreting and reapplying Qurānic prescription to ever-evolving circumstances of Muslim societies. By cutting the Qurān loose from its theological

83 Sheehan, The Enlightenment Bible.

84 On the deeper roots of this tradition that reconsidered the value of the Biblical text for Qurānic commentary, see S.J. Ross, “The Biblical Turn in Modern Qur'an Commentary" (PhD dissertation, Yale University, 2018).

85 Troll, Sayyid Ahmad Khan; Ch.W. Troll, Ch. M. Ramsey, and M. Basharat Mughal, The Gospel According to Sayyid Ahmad Khan (1817-1898): An Annotated Translation of Tabyīn al-kalām (Part 3) (Leiden: Brill, 2020).

86 The accessibility of the Bible to ordinary Russian Orthodox believers was a contested issue throughout the nineteenth century. The first complete Bible in the Russian language was translated and authorised by the Russian Orthodox Church only in 1878. S.K. Batalden, Russian Bible Wars: Modern Scriptural Translation and Cultural Authority (Cambridge: Cambridge University Press, 2013): 125 .

87 Murza Alim, “Letter to N. Ostroumov (24 April 1883)": fol. 8v.-9r. 
moorings, Gasprinskii presented it as an important but merely cultural artefact, a historical source that taught no more than universal values. He acknowledged that in the early centuries of Islam, "the Qur'ān gave the Muslims many useful laws, supplemented by even more numerous sayings (hadith) of the Prophet, related to the areas of law and communal life"; however, with societies becoming larger and more complex, Muslims had to rely on reason to move beyond "basic Islamic laws in order to be able to respond to the movement of life." 88 To redefine the value of the Qurān in the present, Gasprinskii made a distinction between the sources and practices of Islamic law (for him, a relic of the past) on the one hand, and universal ethical norms on the other. According to Gasprinskii, the Qurān-if its message is uncorrupted — represents a book of ethical postulates: a collection of eternal propositions intended to serve ethical, spiritual and religious purposes in Muslims' everyday lives:

If these gentlemen [the Russian critics of Islam] made an effort to study [the Qur'ān] from the universal philosophical and social point of view [emphasis added, G.S.], they would have paid attention to the original form of [Islam] as it came out of the hands of the prophet Mahomed and during the first caliphates-before the Mongol invasion, before the impurity of the ignorant and then class fanaticism. ${ }^{89}$

In this picture presented by Gasprinskii, the Qurān receives a new designated space as a foundation, as the ethical framework of Russia's Muslim community, decoupled from traditional methods of reading it and the associated embodied practices. With this perspective, he is not only suggesting the eternity and universality of these values: for him, these values are also in line with Orthodox Christian norms that underlie Russian society. As he advocates seeing the Qurān and the Bible as containing essentially the same message, he regards (secular) education as key for Muslims and Christians to understand both their own and the other's religious teaching. ${ }^{90}$

88 I. Gasprinskii, "Islam i tsivilizatsiia", Tarjuman/Perevodchik 40 (11 November 1884), following Gasprinskii, Polnoe sobranie sochinenii: 240. Similar ideas were later expressed by Mūsā Jārullāh Bigi in Khalï nazarïna bernīchä mäsälä (Kazan, 1912) and by Muḥammad 'Abduh. The latter believed that the Qurān was addressed primarily to the pagan Arabs of the seventh century; thus, the text must be interpreted within the worldview that dominated among the Arabs of that period, cf. N. Abu Zayd, Reformation of Islamic Thought: A Critical Historical Analysis (Amsterdam: Amsterdam University Press, 2006): 20.

89 Murza Alim, "Letter to N. Ostroumov (24 April 1883)": fol. 8r.

$90 \quad$ I. Gasprinskii, "Letter to N. Ostroumov (Bakhchisarai, 1883)." The National Archive of the Republic of Tatarstan, 968-1-72. 
In explicating Christian and Muslim belief as not competitive but inherently convergent, Gasprinskii's ideas resonate in strategy with Aḥmad Khān's philosophy, although the latter developed a theologically much deeper and more complex standpoint. Shifting the modes in interpreting the Scripture, both Gasprinskii and Ahmad Khān bowed to the primacy of human reason and thus pushed Islam's discursive traditionality aside, promoting instead what Saba Mahmood has called "secular hermeneutics".91

\section{Conclusion}

In sum, although Muslims' use of the term 'Islamic Reformation' seems, at least at first glance, to mark not only the physical but also the intellectual dominance of European colonial powers over their Muslim subjects, it transpires upon closer examination to offer a useful insight into the intricate power dynamics that existed between the ruler and the ruled in various colonial settings throughout the nineteenth century. Adopting and internalising the idea that Muslim societies needed reform did not mean an unconditional surrender and lack of agency on the part of Muslims in the face of European and elite hegemony. On the contrary, hybrid individuals like Gasprinskii and Aḥmad Khān, who straddled boundaries and were members of a number of distinct groups, interacted with and challenged various cultural codes to eventually create projects of modernity that deliberately diverged from European models. Viewing Gasprinskii through this lens, as an agent who engaged in subtle and continuous blurring of borders between Russianness, Europeanness, and Muslimness, speaks to the growing body of scholarship that imagines modernisation and change in Russia at the turn of the twentieth century without reinforcing the image of a dramatic rupture with the past.

Using the concept of Islamic Reformation, Gasprinskii attempted to resituate Islam, and the Qurān in particular, within the Russian cultural context that emerged in the empire by the 185 os and evolved further during the Great Reforms. His approach was intended to enable the interpretation of religious beliefs or practices in terms of a moral and potentially national community: more emphasis was placed on issues such as education, comportment

91 On Mahmood's use of the term in relation to post-9/11 discourses on Islam that use certain tropes similar to the ones discussed in fin-de-siècle discourses, see S. Mahmood, "Secularism, Hermeneutics, and Empire: The Politics of Islamic Reformation." Public Culture 18/2 (2006): 323-47. For a response to Mahmood, see Y. Jansen, "Postsecularism, Piety and Fanaticism: Reflections on Jürgen Habermas' and Saba Mahmood's Critiques of Secularism." Philosophy \& Social Criticism 37/9 (2011): 977-98. 
and ethics, rather than on specifically religious matters. Simultaneously, he engaged in designing a particular kind of religious subject that was compatible with the rationality and nation-building project developed by major elites of the Russian empire.

Importantly, the idea of 'Islamic Reformation' continued to function in the Russian public sphere as a political concept (i.e. not as a fixed notion, but rather as an index of problems) well into the twentieth century. Many of Gasprinskii's interpretations of the term that were initially tailored exclusively for his Russian-language audience were appropriated for intra-Muslim debates by the new Muslim elites, who were graduates of reformed madrasas. Mūsā Jārullāh Bigi (1875-1949), writer and politician Iusuf Akçura (1876-1935), historian and educator Hādī Atlasi (1876-1938) and Kashshāf Tarjemani (1877-1943), qạ̄̂i and imam of a mosque in Kazan, later co-opted the concept for a broad array of competing projects. ${ }^{92}$ This continuously evolving multi-layeredness of the Islamic Reformation concept and its embeddedness in hegemonic practices of power demand further research, especially given the restless revisions in present-day Russia of Muslim reformists' projects designed to shape 'russkii' Islam (in the contemporary interpretation, 'rossiiskii' Islam), ${ }^{93}$ as well as the persistence of the 'Islam-needs-a-Reformation' trope in Islamophobic discourses globally. ${ }^{94}$

\section{Acknowledgements}

This work was supported by a grant from the European Research Council as part of the European Union Horizon 2020 Research and Innovation Programme (grant agreement no. 810141, the EuQu project: "The European Qur'ān. Islamic Scripture in European Culture and Religion 1115-1850"). The author would like to thank Dr Ol'ga Bessmertnaia, Dr Michael Kemper, Dr Il'ia Kukulin, and Dr Maria Mayofis for providing research material and insightful feedback on

92 A. Knysh, "Reformatsiia, kotoraia ne sostoialas', ili chto by skazal Musa Bigiev segodnia?", Rossiia i musul'manskii mir 4/298 (2017):135-42; Ch. Kurzman, Modernist Islam, 1840-1940: A Sourcebook (Oxford: Oxford University Press, 2002): Section 4.

93 M. Kemper, "Religious Political Technology: Damir Mukhetdinov's 'Russian Islam." Religion, State and Society 47/2 (2019): 214-33.

94 E.g. M. Hasan, “Why Islam Doesn't Need a Reformation." The Guardian, 17 May 2015, http:// www.theguardian.com/commentisfree/2015/may/17/islam-reformation-extremism -muslim-martin-luther-europe; Th. Hobson, “Why Calling for an 'Islamic Reformation' Is Lazy and Historically Illiterate." The Spectator, 7 February 2015, https://www.spectator .co.uk/article/why-calling-for-an-islamic-reformation-is-lazy-and-historically-illiterate. 
the earlier drafts of this paper, as well as three anonymous reviewers for their in-depth comments.

\section{Bibliography}

Abu Zayd, Nasr. 2006 Reformation of Islamic Thought: A Critical Historical Analysis (Amsterdam: Amsterdam University Press, 2006): 20.

Almazova, Leila. 2020. Nezatikhaiushchie spory vokrug fenomena tatarskogo dzhadidizma. Islamology 10/2: 180-87.

Aschim, Anders. 2019. Luther and Norwegian Nation-Building. Nordlit 43: 127-141.

Aydin, Cemil. 20og. The Question of Orientalism in Pan-Islamic Thought: The Origins, Content and Legacy of Transnational Muslim Identities. In From Orientalism to Postcolonialism: Asia, Europe and the Lineages of Difference, eds. Sucheta Mazumdar, Vasant Kaiwar, Thierry Labica. London: Routledge: 107-28.

Aydin, Cemil. 2016. Imperial Paradoxes: A Caliphate for Subaltern Muslims. ReOrient 1/2: 171-91.

Aydin, Cemil. 2017. The Idea of the Muslim World: A Global Intellectual History. Cambridge, MA: Harvard University Press.

Baiazitov, Ataulla. 1883. Vozrazhenie na rech' Ernesta Renana. Islam i nauka. St. Petersburg: Tipografiia A.S. Suvorina.

Batalden, Stephen K. 2013. Russian Bible Wars: Modern Scriptural Translation and Cultural Authority. Cambridge: Cambridge University Press.

Batunskii, Mark A. 1996. Pravoslavie, islam i problemy modernizatsii v Rossii na rubezhe XIX-XX vekov. Obshchestvennye nauki i sovremennost' 2: 81-9o.

Bekkin, Renat. 2016. Vasilii Velichko i ego proekt 'Ataulla Baiazitov—russkii publitsist'. Bel'skie prostory 10: 152-6o.

Berlin, Isaiia. 2001. Istoriia svobody. Rossiia. Moscow: NLO.

Bessmertnaia, Olga. 2017. Tol'ko li marginalii? Tri epizoda s 'musul'manskim russkim iazykom' v pozdnei Rossiiskoi imperii. Islamology 7/1: 140-79.

Bessmertnaia, Olga. 2019. Ponimanie istorii i identichnost' avtora v vozrazheniiakh Ataully Baiazitova Ernestu Renanu. Islamology 9/1-2:54-82.

Bhabha, Homi K. 1994. The Location of Culture. London: Routledge.

Burke, Peter. 2009. Cultural Hybridity. Cambridge: Polity Press.

Devji, Faisal. 2007. Apologetic Modernity. Modern Intellectual History 4/1: 61-76.

Devlet-Kil'deev, A. 1881. Magomet kak prorok. St. Petersburg: Tipografiia A.S. Suvorina.

DeWeese, Devin. 2016. It Was a Dark and Stagnant Night ('til the Jadids Brought the Light): Clichés, Biases, and False Dichotomies in the Intellectual History of Central Asia. Journal of the Economic and Social History of the Orient 59/1-2: 37-92. 
Dmitriev, Andrei. 2012. Preodolenie 'veroispovednoi ksenofobii': Tema staroobriadchestva v russkoi literature 1870-188o-kh gg. Vestnik RKHGA 13/4: 180-89.

El Shamsy, Ahmed. 2020. Rediscovering the Islamic Classics: How Editors and Print Culture Transformed an Intellectual Tradition. Princeton, NJ: Princeton University Press.

Ergin, Murat. 2016. "Is the Turk a White Man?": Race and Modernity in the Making of Turkish Identity. Leiden: Brill.

Etkind, Aleksandr. 2013. Internal Colonization: Russia's Imperial Experience. Hoboken, NJ: John Wiley \& Sons.

Fedyashin, Anton A. 2012. Liberals under Autocracy: Modernization and Civil Society in Russia, 1866-1904. Madison, WI: University of Wisconsin Press.

Frank, Allen J. 2012. Bukhara and the Muslims of Russia: Sufism, Education, and the Paradox of Islamic Prestige. Leiden: Brill.

Gasprinskii, Ismail. 1881. Russkoe musul'manstvo. Mysli, zametki i nabliudeniia. Simferopol: Tipografiia Spiro.

Gasprinskii, Ismail. 1883a. Letter to N. Ostroumov. Bakhchisarai, No date. Kazan: The National Archive of the Republic of Tatarstan: 968-1-72.

Gasprinskii, Ismail. 1883b. Sud'by magometanstva. Tarjuman/Perevodchik 10 (June 10). Gasprinskii, Ismail. 1884. Islam i tsivilizatisiia. Tarjuman/Perevodchik 22 (June 17).

Gasprinskii, Ismail. 2017. Polnoe sobranie sochinenii. Ranniaia publitsistika 1879-1886. Vol. 2. Ed. Rafael' Khakimov. Kazan, Simferopol: Institut Istorii im. Sh. Mardzhani.

Geraci, Robert. 2001. Window on the East: National and Imperial Identities in Late Tsarist Russia. Ithaca, NY: Cornell University Press.

Gorshenina, Svetlana. 2019. Izobretenie kontsepta Srednei/Tsentral'noi Azii. Washington, DC: Central Asia Program.

Guida, Michelangelo. 2011. Al-Afghānī and Namık Kemal's Replies to Ernest Renan: Two Anti-Westernist Works in the Formative Stage of Islamist Thought. Turkish Journal of Politics 2/2: 57-70.

Harvey, Andrew Edward. 1918. Martin Luther in the Estimate of Modern Historians. The American Journal of Theology 22/3: 321-48.

Hasan, Mehdi. 2015. Why Islam Doesn't Need a Reformation. The Guardian, May 17. http://www.theguardian.com/commentisfree/2015/may/17/islam-reformation -extremism-muslim-martin-luther-europe.

Hobson, Theo. 2015. Why Calling for an 'Islamic Reformation' is Lazy and Historically Illiterate. The Spectator, February 7. https://www.spectator.co.uk/article/why-calling -for-an-islamic-reformation-is-lazy-and-historically-illiterate.

Hourani, Albert. 1983. Arabic Thought in the Liberal Age 1798-1939. Cambridge: Cambridge University Press. 
Hussain, Khurram. 2019. Islam as Critique: Sayyid Ahmad Khan and the Challenge of Modernity. London: Bloomsbury Publishing.

Jansen, Yolande. 2011. Postsecularism, Piety and Fanaticism: Reflections on Jürgen Habermas' and Saba Mahmood's Critiques of Secularism. Philosophy \& Social Criticism 37/9: 977-98.

Jones, Stephen H., Rebecca Catto, Tom Kaden, and Fern Elsdon-Baker. 2019. 'That's How Muslims are Required to View the World': Race, Culture and Belief in Non-Muslims' Descriptions of Islam and Science. The Sociological Review 67/1: 161-77.

Kalmbach, Hilary. 2020. Islamic Knowledge and the Making of Modern Egypt. Cambridge: Cambridge University Press.

Keddie, Nikki R. 1968. An Islamic Response to Imperialism. Political and Religious Writings of Sayyid Jamal ad-Din "al-Afghani." Berkeley, CA: University of California Press.

Kemper, Michael. 1998. Sufis und Gelehrte in Tatarien und Baschkirien, 1789-1889: Der islamische Diskurs unter russischer Herrschaft. Berlin: Klaus Schwarz Verlag.

Kemper, Michael. 2018. Ismail Gasprinskij's 'Russisches Muslimentum' (1881). Frankfurter Zeitschrift für islamisch-theologische Studien 4: 125-38.

Kemper, Michael. 2019a. Muslim EuRossocentrism. Ismail Gasprinskii’s 'Russian Islam' (1881). In Eurocentrism in European History and Memory, eds. Marjet Brolsma, Robin de Bruin, and Matthijs Lok. Amsterdam: Amsterdam University Press: 79-101.

Kemper, Michael. 2019b. Religious Political Technology: Damir Mukhetdinov's 'Russian Islam.' Religion, State and Society 47/2: 214-33.

Kerimov, Ismail (ed.). 20o6. Slovar'trudnykh slov krymskotatarskogo iazyka. Simferopol: Tavrida.

Khalid, Adeeb. 1999. The Politics of Muslim Cultural Reform. Berkeley, CA: University of California Press.

Khan, Sir Sayyid Ahmmad. 1873. The Causes of the Indian Revolt. Benares: Medical Hall Press.

Knysh, Alexander. 2017. Reformatsiia, kotoraia ne sostoialas', ili chto by skazal Musa Bigiev segodnia? Rossiia i musul'manskii mir 4: 135-42.

Kohn, Margaret. 20og. Afghānī on Empire, Islam, and Civilization. Political Theory 37/3: 398-422.

Kotiukova, Tat'iana and Igor' Alekseev. 2012. Pis'ma Murzy Alima i Gasprinskogo k N.P.Ostroumovu iz lichnogo arkhiva N.I.Il'minskogo. Paper presented at the conference "I Bakhchisaraiskie nauchnye chteniia pamiati I. Gasprinskogo", Bakhchisarai, $5^{-6}$ April.

Krevsky, Elena. 1999. The Scar of the Schism: The Image of Old Believers in Late Nineteenth-Century Russian Literature. Historical Papers. Online: http://pi.library .yorku.ca/ojs/index.php/historicalpapers/article/view/39396. 
Kurzman, Charles and Michaelle Browers. 2004. Introduction. In An Islamic Reformation? New York, NY: Lexington Books: 1-17.

Kurzman, Charles. 2002. Modernist Islam, 1840-1940: A Sourcebook. Oxford: Oxford University Press.

Lazzerini, Edward J. 1973. Ismail Bey Gasprinskii and Muslim Modernism in Russia: 1878-1914. PhD dissertation, University of Washington.

Lazzerini, EdwardJ. 1984. From Bakhchisarai to Bukhara in 1893: Ismail Bey Gasprinskii's Journey to Central Asia. Central Asian Survey 3/4: 77-88.

Legaspi, Michael C. 2010. The Death of Scripture and the Rise of Biblical Studies. Oxford: Oxford University Press.

Mahmood, Saba. 20o6. Secularism, Hermeneutics, and Empire: The Politics of Islamic Reformation. Public Culture 18/2: 323-47.

Malik, Jamal. 1996. Muslim Identities Suspended between Tradition and Modernity. Comparative Studies of South Asia, Africa and the Middle East 16/2: 1-9.

Marsden, Thomas. 2015. The Crisis of Religious Toleration in Imperial Russia: Bibikov's System for the Old Believers, 1841-1855. Oxford: Oxford University Press.

Meyer, James H. 2014. Turks Across Empires: Marketing Muslim Identity in the Russian-Ottoman Borderlands, 1856-1914. Oxford: Oxford University Press.

Miller, Aleksei. 2016. Natsiia, ili mogushchestvo mifa. St. Petersburg: Izdatel'stvo Evropeiskogo universiteta.

Morrison, Alexander. 2006. Russian Rule in Turkestan and the Example of British India, c. 186o-1917. The Slavonic and East European Review 84/4: 666-707.

Murav, Harriet. 2003. Identity Theft: The Jew in Imperial Russia and the Case of Avraam Uri Kovner. Palo Alto, CA: Stanford University Press.

Murza Alim. 1882a. Islam i magometanstvo. Sankt-Peterburgskie Vedomosti 18o (July 6). Murza Alim. 1882b. Islam i magometanstvo. Sankt-Peterburgskie Vedomosti 188 (July 14). Murza Alim. 1883a. Letter to N. Ostroumov. St. Petersburg, 24April. Kazan: The National Archive of the Republic of Tatarstan: 968-1-72.

Murza Alim. 1883b. Letter to N. Ostroumov. Bakhchisarai, 7 May. Kazan: The National Archive of the Republic of Tatarstan: 968-1-72.

Musul'manin. 1883. Musul'manstvo i ratsionalizm. Vostochnoe obozrenie 24 (16 June).

Nabiev, Rinat A. and Anvar A. Gafarov. 2011. Problemy religioznoi tolerantnosti v trudakh musul'manskikh modernistov vo vtoroi polovine XIX-nachale XX vv. Uchenye zapiski Kazanskogo universiteta 153/3: 120-30.

Nikitin, Avgustin. 1997. Russkie, slavianofily i nemetskoe liuteranstvo. Nachalo 5. Online: https://slovo-bogoslova.ru/nachalo/russkie-slavyanofily-i-nemeckoe-lyuter/.

Noack, Christian. 2000. Muslimischer Nationalismus im russischen Reich: Nationsbildung und Nationalbewegung bei Tataren und Baschkiren: 1861-1917. Stuttgart: Franz Steiner Verlag. 
Özgür Tuna, Mustafa. 2002. Gaspirali v. Il'minskii:Two Identity Projects for the Muslims of the Russian Empire. Nationalities Papers 30/2: 265-89.

Palti, Elías José. 2014. The 'Theoretical Revolution' in Intellectual History: From the History of Political Ideas to the History of Political Languages. History and Theory 53/3: 387-405.

Rabow-Edling, Susanna. 2012. Slavophile Thought and the Politics of Cultural Nationalism. Albany, NY: sunY Press.

Renner, Andreas. 2003. Defining a Russian Nation: Mikhail Katkov and the 'Invention' of National Politics. The Slavonic and East European Review 81/4: 659-82.

Robinson, Francis. 2008. Islamic Reform and Modernities in South Asia. Modern Asian Studies 42/2-3: 259-81.

Ross, Danielle. 2020. Tatar Empire: Kazan's Muslims and the Making of Imperial Russia. Bloomington, IN: Indiana University Press.

Ross, Samuel J. 2018. The Biblical Turn in Modern Qur'an Commentary. PhD dissertation, Yale University.

Ruud, Charles A. 2009. Fighting Words: Imperial Censorship and the Russian Press, 18041906. Toronto: University of Toronto Press.

Saikia, Yasmin and M. Raisur Rahman. 2019. The Cambridge Companion to Sayyid Ahmad Khan. Cambridge: Cambridge University Press.

Sartori, Paolo. 2016. Ijtihād in Bukhara: Central Asian Jadidism and Local Genealogies of Cultural Change. Journal of the Economic and Social History of the Orient 59/1-2: $193-236$.

Seitmemetova, Sel'vina. 2015. Iz lichnoi biblioteki Ismaila Gasprinskogo. Bakhchisaraiskii Muzei-Zapovednik. Online: https://handvorec.ru/novosti/iz-lichnoj-biblioteki-ismaila -gasprinskogo/.

Sheehan, Jonathan. 2013. The Enlightenment Bible: Translation, Scholarship, Culture. Princeton, NJ: Princeton University Press.

Siddiqi, Mazheruddin. 1967. Religious Thought of Sir Sayyid Ahmad Khan. Islamic Studies 6/3: 290-308.

Sukidi. 2005. The Traveling Idea of Islamic Protestantism: A Study of Iranian Luthers. Islam and Christian-Muslim Relations 16/4: 401-12.

Suny, Ronald Grigor. 20o1. The Empire Strikes Out: Imperial Russia, 'National' Identity, and Theories of Empire. In A State of Nations: Empire and Nation-Making in the Age of Lenin and Stalin, eds. Ronald Grigor Suny and Terry Martin. Oxford: Oxford University Press: $23-66$.

Tikhonova, Nadezhda. 2019. Rol' krymskotatarskoi gazety ‘Perevodchik-Terdzhiman’ v etnokul'turnom i politicheskom diskurse v Rossii v 1880-1910-e gg. PhD dissertation, St. Petersburg State University.

Tolz, Vera. 2011. Russia's Own Orient: The Politics of Identity and Oriental Studies in the Late Imperial and Early Soviet Periods. Oxford: Oxford University Press. 
Troll, Christian W. 1978. Sayyid Ahmad Khan: A Reinterpretation of Muslim Theology. Noida: Vikas Publishing House.

Troll, Christian W., Charles M. Ramsey, and Mahboob Basharat Mughal. 2020. The Gospel According to Sayyid Ahmad Khan (1817-1898): An Annotated Translation of Tabyīn al-kalām (Part 3). Leiden: Brill.

Tuna, Mustafa. 2015. Imperial Russia's Muslims: Islam, Empire and European Modernity, 1788-1914. Cambridge: Cambridge University Press.

Valitskii, Andzhei. 2019. Vkrugu konservativnoi utopii. Struktura i metamorfozy russkogo slavianofil'stva. Moscow: NLO.

Vdovin, Aleksei and Andrei Fedotov. 2018. Kak izuchat' Katkova segodnia. Novoe literaturnoe obozrenie (153). Online: https://www.nlobooks.ru/magazines/novoe_litera turnoe_obozrenie/153/article/2019o/.

Velizhev, Mikhail. 2019. Tsivilizatsiia, ili voina mirov. St. Petersburg: Izdatel'stvo Evropeiskogo universiteta.

Vengerov, Semen A. (ed.). 1889-1904. Devlet-Kil'deev. In Kritiko-biograficheskii slovar' russkikh pisatelei i uchenykh. St. Petersburg: Semenovskaia tipo-litografiia. Online available at https://dic.academic.ru/dic.nsf/enc_biography/Девлет.

von Kügelgen, Anke. 2013. 'Progressiver Islam' im Ausgehenden Zarenreich: Das Plädoyer des St. Petersburger Imams und Regierungsbeamten Ataulla Bajazitov (1846-1911) für die Partizipation der Muslime an der modernen Zivilisation. Asiatische Studien/Études Asiatiques 67/3: 927-64.

Wasti, Syed Tanvir. 2010. Sir Syed Ahmad Khan and the Turks. Middle Eastern Studies 46/4: 529-42.

Werbner, Pnina and Tariq Modood. 2015. Debating Cultural Hybridity: Multicultural Identities and the Politics of Anti-Racism. London: Zed Books Ltd.

Werth, Paul W. 2002. Atthe Margins of Orthodoxy:Mission, Governance, and Confessional Politics in Russia's Volga-Kama Region, 1827-1905. Ithaca, NY: Cornell University Press.

Wiese, Christian. 2009. 'Let His Memory Be Holy to Us!': Jewish Interpretations of Martin Luther from the Enlightenment to the Holocaust. The Leo Baeck Institute Year Book 54/1: 93-126.

Wilson, M. Brett. 2014. Translating the Qur'an in an Age of Nationalism: Print Culture and Modern Islam in Turkey. Oxford: Oxford University Press.

Zorin, Andrei. 2001. Kormia dvuglavogo orla. Russkaia literatura i gosudarstvennaia ideologiia v Rossii v poslednei treti XVIII_pervoi treti XIX veka. Moscow: NLO. 